\title{
Sosialisasi Protokol Kesehatan 3M pada Siswa SMP Negeri 26 Malang untuk Menghadapi Era Kenormalan Baru Pasca Pandemi COVID-19
}

\section{(Socialization of 3M Health Protocol to Students of SMP Negeri 26 Malang to Face the New Normal Era after the COVID-19 Pandemic)}

\author{
Eri Yusnita Arvianti ${ }^{1 *}$, Herdiana Anggarasari ${ }^{2}$, Wahidyanti Rahayu Hastutiningtas ${ }^{3}$ \\ ${ }^{1,2}$ Program Studi Agribisnis, Fakultas Pertanian, Universitas Tribhuwana Tunggadewi-Malang \\ ${ }^{3}$ Program Studi Ilmu Kesehatan, Fakultas Ilmu Kesehatan, Universitas Tribhuwana Tunggadewi-Malang
}

\begin{tabular}{|c|c|}
\hline ARTICLE INFO & ABSTRAK \\
\hline $\begin{array}{l}\text { Article history } \\
\text { Received : } 28 \text { April } 2021 \\
\text { Revised : } 30 \text { Mei } 2021 \\
\text { Accepted : 08 Juni } 2021 \\
\text { DOI : } \\
\text { https://doi.org/10.33366/jast. } \\
\text { v5i1.2388 }\end{array}$ & $\begin{array}{l}\text { Kondisi saat ini meskipun covid-19 masih ada, namun sudah memasuki era } \\
\text { kenormalan baru. Selama ini bidang pendidikan menerapkan pembelajaran } \\
\text { daring, mulai berlangsung lagi secara tatap muka, namun tetap mengikuti } \\
\text { aturan dan protokol kesehatan. Protokol kesehatan diterapkan bertujuan } \\
\text { untuk melindungi seluruh komponen yang ada di sekolah dari resiko } \\
\text { penularan Covid-19. SMP Negeri } 26 \text { Malang juga mulai menggelar } \\
\text { kegiatan belajar secara tatap muka. Kegiatan belajar tersebut dimulai } \\
\text { tanggal } 19 \text { April } 2021 \text { yang dilakukan secara bertahap. Oleh karena itu } \\
\text { siswa-siswa SMP Negeri } 26 \text { membutuhkan sosialisasi terkait dengan } \\
\text { protokol kesehatan selama mereka melakukan kegiatan pembelajaran tatap } \\
\text { muka. Sosialisasi ini bertujuan untuk memberikan informasi kepada siswa- } \\
\text { siswi SMP Negeri } 26 \text { Malang terkait pencegahan covid-19 dengan } \\
\text { menerapkan protokol kesehatan yaitu } 3 \mathrm{M} \text { (menjaga jarak, memakai masker, } \\
\text { dan mencuci tangan) agar terhidar dari penularan covid-19. Hasil dari } \\
\text { sosialisasi ini yaitu mayoritas siswa dan siswi SMP Negeri } 26 \text { Malang telah } \\
\text { memahami terkait dengan cara penularan dan pencegahan covid-19 } \\
\text { menggunakan protokol kesehatan } 3 \mathrm{M} \text {. }\end{array}$ \\
\hline
\end{tabular}

\section{PENERBIT}

\section{UNITRI PRESS}

Jl. Telagawarna, Tlogomas-

Malang, 65144, Telp/Fax: 0341565500

\section{(®) $\odot \odot$}

This is an open access article under the Creative Commons AttributionShareAlike $4.0 \quad$ International License. Any further distribution of this work must maintain attribution to the author(s) and the title of the work, journal citation and DOI. $\underline{\mathrm{CC}-\mathrm{BY}-\mathrm{SA}}$

\section{ABSTRACT}

The current condition, even though Covid-19 still exists, it has entered a new era of normality. So far, the education sector has implemented online learning, which has begun to take place face-to-face again but still follows health rules and protocols. The health protocol is implemented to protect all components in schools from the risk of Covid-19 transmission. SMP Negeri 26 Malang has also started to hold face-to-face learning activities. The learning activity began on April 19, 2021, which was carried out in stages. Therefore, SMP Negeri 26 need socialization related to health protocols as long as they carry out face-to-face learning activities. This socialization aims to provide information to SMP Negeri 26 Malang students regarding the prevention of covid-19 by implementing the health protocol, namely $3 M$ (keeping a distance, wearing masks, and washing hands) to avoid covid-19 transmission. The results of this socialization are that students and students of SMP Negeri 26 Malang have understood the ways of transmission and prevention of Covid-19 using the $3 M$ health protocol.

Cara Mengutip : Arvianti, E. Y., Anggarasari, H., Hastutiningtas, W. R (2021). Sosialisasi Protokol Kesehatan 3M pada Siswa SMP Negeri 26 Malang untuk Menghadapi Era Kenormalan Baru Pasca Pandemi COVID-19. JAST : Jurnal Aplikasi Sains dan Teknologi, 5(1), 69-75. doi:https://doi.org/10.33366/jast.v5i1.2388 


\section{PENDAhULUAN}

World Health Organization (WHO) menyatakan bahwa terdapat wabah penyakit baru yaitu virus korona (COVID-19) pada Maret 2020 [1]. Dengan tidak ada vaksin yang tersedia, dibutuhkan tindakan pencegahan salah satunya yang paling banyak dilakukan yaitu social distancing [2]. Pada bulan-bulan awal pandemi COVID-19, sebagian besar negara berusaha mengendalikan penyebaran infeksi dengan mengurangi tingkat kontak antara orang yang membawa virus dan mereka yang belum terinfeksi [3]. Selain itu untuk menanggapi pandemi COVID-19 global, negara-negara di dunia menerapkan serangkaian kebijakan kesehatan masyarakat yang dirancang untuk memperlambat penularan. Kemampuan pemerintah untuk menegakkan kebijakan yaitu dengan mengatur perilaku individu misalnya memberikan jarak fisik (social distancing) dan penggunaan masker [4].

Penambahan kasus terkonfirmasi positif Covid-19 di Indonesia masih fluktuatif. Covid-19 telah memberikan banyak korban jiwa dan berdampak luar biasa terhadap tatanan kehidupan masyarakat dunia dan khusunya di Indonesia. Masyarakat diminta untuk berhenti melakukan aktivitas di luar rumah dan menjalankan isolasi mandiri serta bagi masyarakat yang terpaksa menjalankan aktivitas di luar rumah harus mengikuti protokol agar penyebaran virus korona dapat terkendali [5].

Covid-19 juga memberikan dampak dalam dunia pendidikan dimulai dari tingkat pendidikan dasar hingga perguruan tinggi. Muncul skema kegiatan pembelajaran yang dibentuk oleh pemerintah sebagai akibat dari adanya pandemi ini [6]. Kebijakan tersebut adalah pembelajaran dilaksanakan secara online atau daring dengan penggunaan internet sehingga pembelajaran tidak dilakukan sebagaimana biasanya yaitu bertatap muka di ruang kelas [7].

Saat ini meskipun covid-19 masih ada, namun sudah memasuki era kenormalan baru. Dalam kondisi seperti ini kebijakan Life New Normal memiliki tujuan untuk menggerakkan kembali akses kegiatan perekonomian masyarakat dan kegiatan pembelajaran dengan memperhatikan dan mengikuti aturan protokol kesehatan yang berlaku [8]. Pembelajaran daring yang selama ini diterapkan di bidang pendidikan, mulai dijalankan kembali dengan dengan tetap memperhatikan, mengikuti dan mematuhi protokol kesehatan [9]. Protokol Kesehatan diterapkan bertujuan untuk melindungi seluruh komponen sekolah dari resiko penularan Covid-19. Nadiem Makarim selaku Menteri Pendidikan dan Kebudayaan menuturkan bahwa sekolah yang akan dibuka bertahap [6]. SMP Negeri 26 Malang mulai mengadakan pembelajaran secara tatap muka dan bertahap. Kegiatan belajar tersebut dimulai tanggal 19 April 2021. Oleh karena itu siswa-siswa SMP Negeri 26 membutuhkan sosialisasi terkait protokol kesehatan selama mereka melakukan kegiatan pembelajaran tatap muka. Perilaku hidup bersih dan sehat sangat penting untuk diketahui demi mencegah penyrbaran covid-19 [10]. Sosialisasi ini memiliki tujuan guna memberikan informasi kepada para siswa SMP Negeri 26 Malang terkait pencegahan covid-19 dengan cara menerapkan dan melakukan protokol kesehatan 
yaitu 3M (menjaga jarak, memakai masker, dan mencuci tangan) agar terhidar dari penularan covid-19.

\section{METODE KEGIATAN}

Kegiatan sosialisasi dilakukan dengan cara penyuluhan yang bertujuan mengedukasi dan meningkatkan pemahaman terkait protokol kesehatan dimana setiap siswa-siswi SMP Negeri 26 harus menjalankannya selama kegiatan belajar tatap muka. Kegiatan sosialisasi diadakan oleh Tim Abdimas yang merupakan dosen di Universitas Tribhuwana Tunggadewi Malang dengan jumlah anggota tim sebanyak 12 orang. Jumlah siswa yang menjadi sasaran sosialisasi yaitu 600 siswa yang terdiri dari 203 siswa kelas VII, 192 siswa kelas VIII dan 205 siswa kelas IX. Lokasi pengabdian masyarakat yaitu di SMP Negeri 26 Malang, Jalan Ikan Gurami No.36, Tunjungsekar, Kec. Lowokwaru, Kota Malang. Penyuluhan dilakukan selama 3 hari yaitu tanggal 19, 20, dan 22 April 2021. Hal tersebut dikarenakan siswa-siswi yang masuk sekolah untuk mengikuti kegiatan pembelajaran secara tatap muka dilakukan secara bertahap selain itu jumlah siswa dalam satu kelas berjumlah 18 siswa sehingga dalam satu kali tatap muka dibagi menjadi 12 kelas. Kelas IX mengikuti kegiatan pembelajaran secara tatap muka pertama kali pada tanggal 19 April 2021, kemudian hari selanjutnya kelas VIII, dan disusul kelas VII. Sasaran dalam penyuluhan ini lebih terfokus pada siswa-siswa SMP Negeri 26 Malang mulai dari kelas VII hingga IX. Materi yang diberikan mengenai pengertian covid-19, pencegahan penularan COVID-19, cara penularan covid-19, bagaimana virus korona menyerang tubuh kita, penerapan protocol kesehatan 3M (menjaga jarak, memakai masker, dan mencuci tangan). Menggunakan alat bantu berupa power point yang berisi materi tulisan dan video. Setelah pemaparan materi, selanjutnya dilakukan umpan balik dan evaluasi terhadap informasi yang disampaikan guna mengetahui tingkat pemahaman dari siswa-siswi SMP Negeri 26 Malang. Metode umpan balik dan evaluasi berupa pertanyaan yang diberikan kepada 3 siswa pada setiap kelas yang dipilih secara acak untuk menjawab pertanyaan terkait dengan materi yang telah disampaikan.

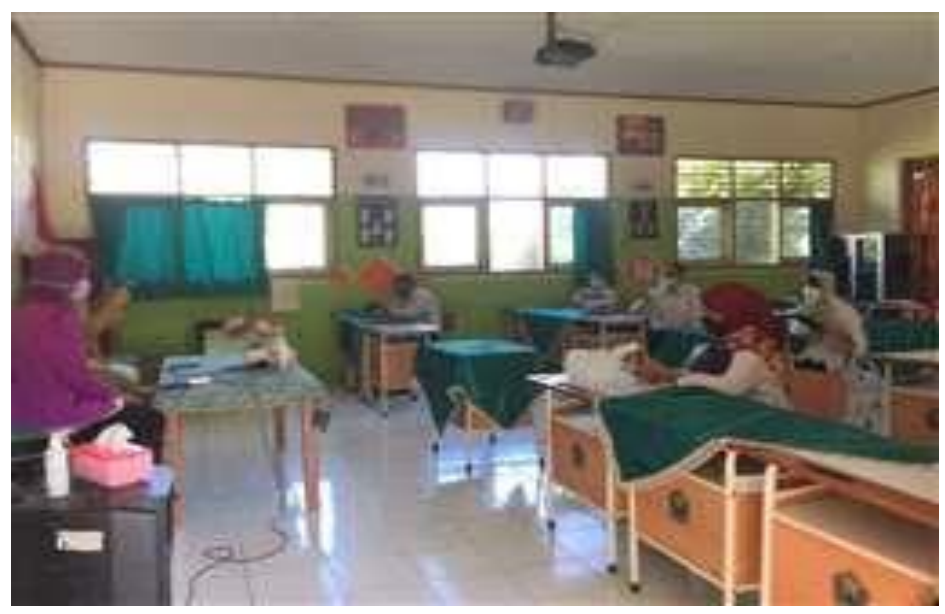

Gambar 1. Persiapan Sebelum Sosialisasi ke Kelas-Kelas di SMP Negeri 26 Malang 


\section{KARYA UTAMA}

Pada awal kegiatan atau sebelum pemaparan materi, tim penyuluh menggali informasi mengenai aktivitas para siswa sebelum diberlakukannya kembali kegiatan pembelajaran tatap muka. Diperoleh hasil yang berbeda-beda. Beberapa siswa mengatakan bahwa mereka hanya di rumah saja dan melakukan kegiatan belajar daring atau online, namun sebagian siswa mengatakan mereka terkadang menjalankan aktivitas di luar rumah yaitu bermain bersama temen di lingkungan yang sama dan berkontak fisik seperti besalaman dengan teman. Selanjutnya dilakukan pemaparan materi mengenai protokol kesehatan yaitu 3M untuk penecegahan penyebaran covid-19 (gambar 2).

Evaluasi dilakukan setelah pemaparan materi yaitu dengan menanyakan pertanyaan kepada 3 siswa yang dipilih secara acak di setiap kelas. Pertanyaan tersebut berkaitan dengan bagaimana cara penularan covid-19 serta apa saja yang harus dilakukan agar terhindar dari penularan covid-19. Tujuan evaluasi adalah untuk mengetahui apakah siswa dan siswi memahami terkait dengan materi yang telah disampaikan oleh tim penyuluh.

Siswa yang mendapatkan kesempatan menjawab pertanyaan yang diajukan oleh pemateri sudah dapat menjelaskan bagaimana cara penularan covid-19 yaitu melalui kontak erat dengan seseorang yang telah positif covid-19 secara langsung melalu berjabat tangan atau terkena domplet penderita covid-19. Selain itu para siswa juga telah memahami bagaimana cara penularan secara tidak langsung yaitu melalui kontak dengan fasilitas publik, misalnya meja restaurant, tombol lift, dan sebagainya. Mereka dapat menjelaskan cara pencegahan menggunakan protokol 3M. Para siswa sudah mengetahui untuk melakukan jaga jarak minimal satu meter, cara menggunakan masker serta cara mencuci tangan yang baik dan benar. Oleh karena itu diasumsikan mayoritas siswa SMP Negeri 26 Malang sudah memahami terkait dengan protokol kesehatan tersebut.

Penerapan protokol kesehatan 3M sangat penting. Menurut Anugerah et al. (2019), masyarakat yang kurang peduli terhadap cara pencegahan covid-19 sangat rentan terkena penyakit ini karena virus korona berada di mana saja dan dapat menulari siapapun.

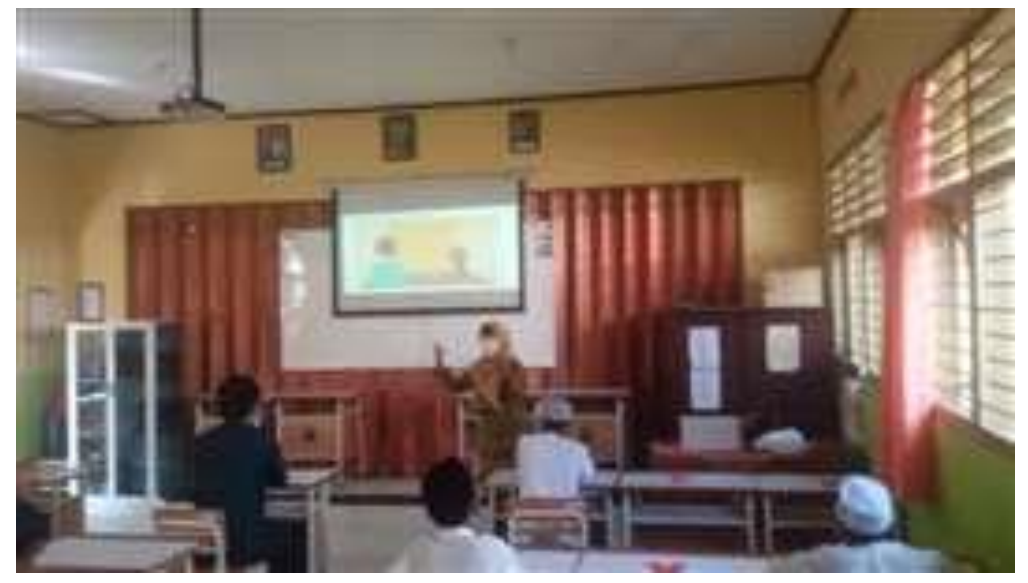

Gambar 2. Pemaparan Materi terkait Covid-19 


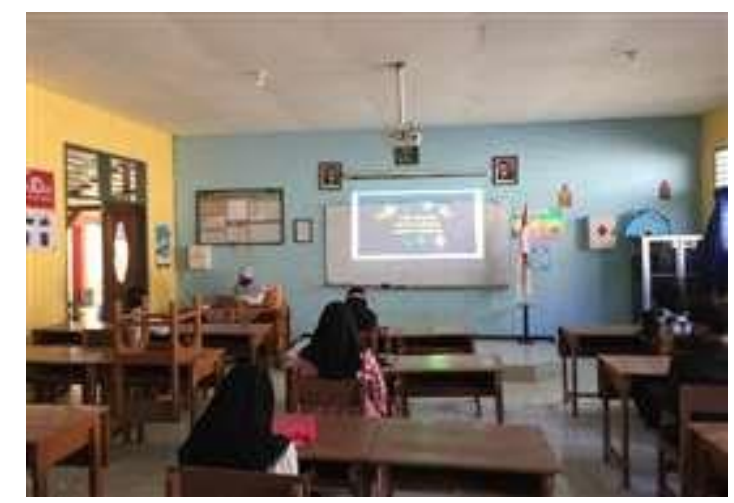

Gambar 3. Pemaparan Materi Menggunakan Video untuk Menarik Perhatian Siswa SMPN 26 Malang

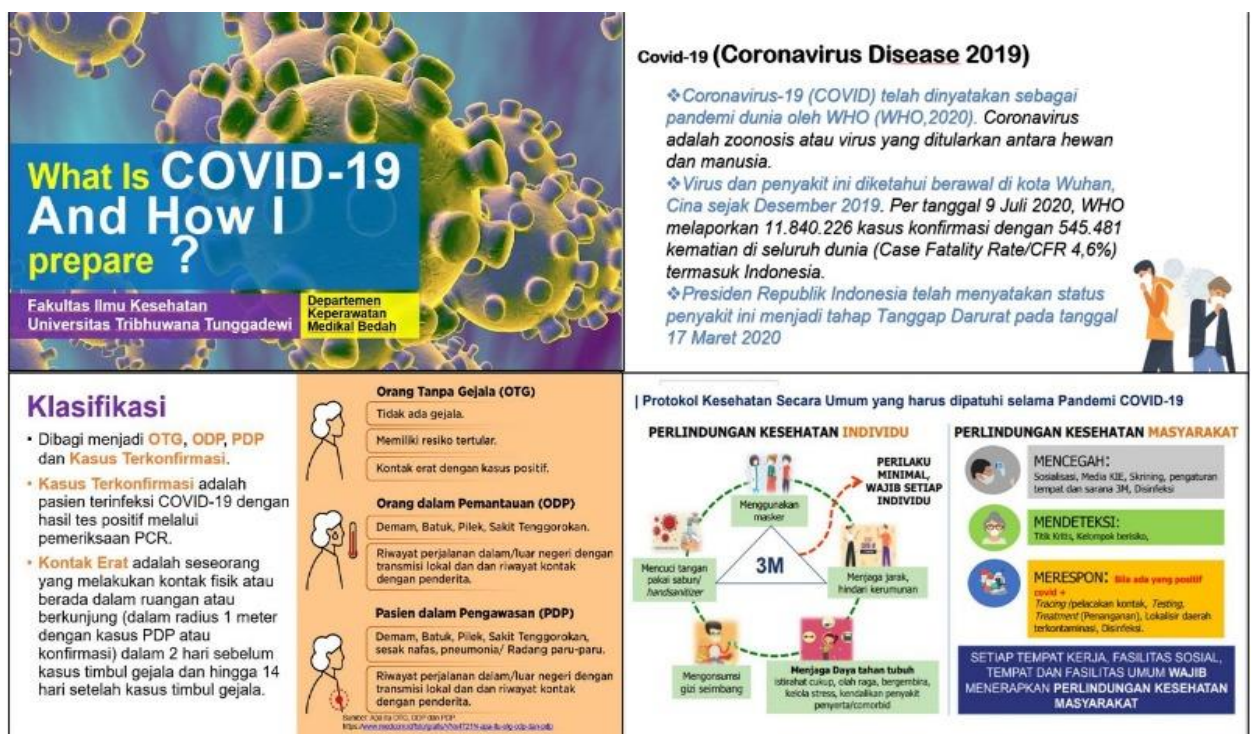

Gambar 4. Salah Satu Materi yang Disampaikan kepada Siswa SMP Negeri 26 Malang

\section{ULASAN KARYA}

Hasil dari sosialisasi ini yaitu dengan cara evaluasi dimana pemateri atau pemyuluh memberikan pertanyaan kepada 3 siswa di setiap kelas yang dipilih secara acak. Hasil evaluasi menunjukkan bahwa setiap siswa yang diberikan pertanyaan terkait dengan covid19 dapat menjawab pertanyaan yang diberikan oleh pemateri. Hal tersebut menunjukkan bahwa sebagian besar siswa SMP Negeri 26 telah memahami terkait dengan bagaiamana cara penularan dan apa saja yang harus dilakukan agar terhindar dari covid-19.

Pada kegiatan ini, pemberian materi masih terbatas dengan metode presentasi dan tidak ada praktik 3M secara keseluruhan yaitu bagaimana cara mencuci tangan yang benar. Selain itu, belum ada pembagian pamflet atau buku saku 3M sehingga program serupa dapat ditingkatkan lagi penyajiannya.

Penilaian peserta atau siswa terhadap sosialisasi ini masih terbatas pada pemberian pertanyaan secara langsung yang dilakukan secara acak kepada 3 siswa di setiap kelasnya sehingga evaluasi belum mencakup pada seluruh siswa. Program selanjutnya setelah pemberian materi setiap siswa dapat diberikan kuesioner atau angket sehingga hasil evaluasi dapat tersaji secara kuantitatif. 
Tanggapan pihak mitra yaitu SMP Negeri 26 Malang terhadap program sosialisasi covid-19 disambut baik dan mengucapkan terima kasih kepada Universitas Tribhuwana Tunggadewi karena telah memberikan edukasi kepada siswa. Kegiatan ini dapat menambah wawasan siswa, selain itu siswa dapat mengaplikasikan dan mengamalkan protokol kesehatan sehingga dapat membantu mengurangi penularan covid-19.

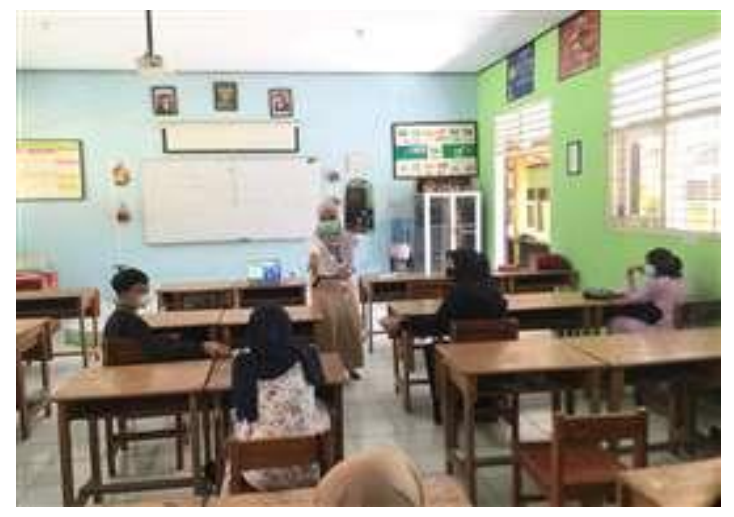

Gambar 5. Evaluasi dengan Mengajukan Pertanyaan kepada Salah Satu Siswa SMPN 26 Malang

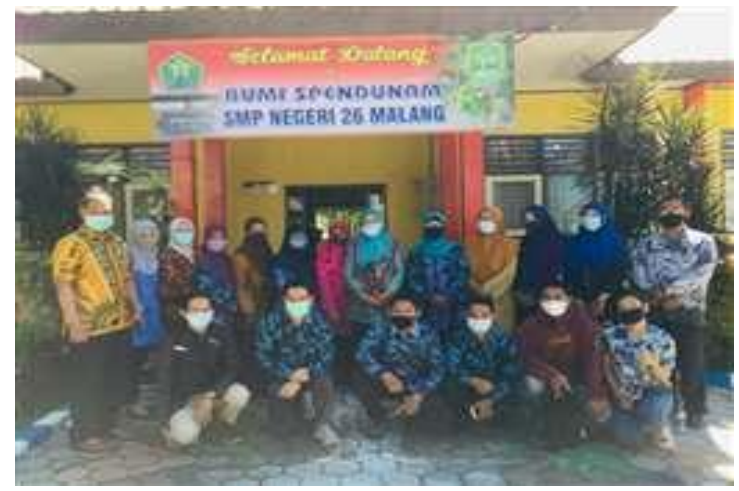

Gambar 6. Tim Abdimas Universitas Tribhuwana Tunggadewi Malang

\section{DAMPAK DAN MANFAAT KEGIATAN}

Kegiatan ini memberikan manfaat dan dampak yang positif setelah pemberian edukasi serta informasi terkait penularan dan pencegahan covid-19 menggunakan protokol kesehatan 3M. Menurut Suni (2020), sistem pernapasan merupakan organ yang akan diserang oleh virus covid-19. Demam, batuk, pilek, sakit tenggorokan, sesak napas, letih, serta lesu adalah gejala yang dialami oleh penderita. Pada kasus yang berat, penderita dapat mengalami pneumonia, sindrom pernapasan akut, sampai kematian. Gejala yang dapat diderita akibat virus tersebut tidak dapat dianggap ringan sehingga sangat penting bagi masyarakat mengetahui cara pencegahan dan penularan virus corona. Sejalan dengan pengabdian masyarakat yang dilakukan di SMP Negeri 26 Malang dengan pemberian edukasi yang menujukkan bahwa hasil edukasi yang diberikan oleh tim penyuluh mengenai bagaimana cara pencegahan dan penularan virus korona dapat meningkatkan pengetahuan para siswa SMP Negeri 26 Malang untuk selalu menerapkan protokol kesehatan yaitu 3M dimanapun berada. 


\section{PENGHARGAAN}

Kami ucapkan terima kasih kepada Rektor Universitas Tribhuwana Tunggadewi Malang, Dewan Pembina dan Pengawas Yayasan Bina Patria Nusantara, dan Tim Abdimas SMP Negeri 26 Malang.

\section{DAFTAR PUSTAKA}

[1] A. Valerisha and M. A. Putra, "Pandemi Global Covid-19 Dan Problematika Negara-Bangsa: Transparansi Data Sebagai Vaksin Socio-Digital?," J. Ilm. Hub. Int., vol. 0, no. 0, pp. 131-137, 2020.

[2] S. Park, B. Kim, and J. Lee, "Social Distancing and Outdoor Physical Activity During the COVID-19 Outbreak in South Korea: Implications for Physical Distancing Strategies," Asia-Pacific J. Public Heal., vol. 32, no. 6-7, pp. 360-362, 2020 .

[3] T. Abel and D. McQueen, "The COVID-19 pandemic calls for spatial distancing and social closeness: not for social distancing!," Int. J. Public Health, vol. 65, no. 3, p. 231, 2020.

[4] C. Bicalho, M. R. Platas, and L. R. Rosenzweig, "'If we move, it moves with us:' Physical distancing in Africa during COVID-19," World Dev., vol. 142, pp. 1-6, 2021.

[5] Nofrita, I. Anita, L. Hermawan, and Dedi Junaedi, "PENERAPAN PROTOKOL KESEHATAN DALAM UPAYA SEKOLAH BEBAS COVID-19," J. Pengabdi. Tri Bhakti, vol. 2, no. 2, pp. 183-190, 2020.

[6] I. Waluyati, Tasrif, and Arif, "Penerapan New Normal Dalam Masa Pandemi Covid 19 di Sekolah,” EduSociata J. Pendidik. Sosiol., vol. III, no. 2, pp. 50-61, 2020.

[7] W. A. F. Dewi, "Dampak COVID-19 terhadap Implementasi Pembelajaran Daring di Sekolah Dasar,” Edukatif J. Ilmu Pendidik., vol. 2, no. 1, pp. 55-61, 2020.

[8] Hosaini and M. Alimin, "Pembelajaran Dalam Era'New Normal' Di Pondok Pesantren Nurul Qarnain Jember Tahun 2020," LISAN AL-HAL J. Pengemb. Pemikir. dan Kebud., vol. 14, no. 2, pp. 361-380, 2020.

[9] S. Bahri and N. Arafah, "Analisis Manajemen SDM Dalam Mengembangkan Strategi Pembelajaran Di Era New Normal," Tafkir Interdiscip. J. Islam. Educ., vol. 1, no. 1 SE-, pp. 20-40, Jan. 2021.

[10] A. Y. Zukmadani, B. Karyadi, and Kasrina, "Edukasi Perilaku Hidup Bersih dan Sehat (PHBS) dalam Pencegahan COVID-19 Kepada Anak-Anak di Panti Asuhan," J. Pengabdi. Masy., vol. 3, no. 1, pp. 68-76, 2020.

[11] M. F. Anugerah, . H., W. Yulianti, and S. Juariah, "Penyuluhan Cuci Tangan Pakai Sabun Di Sdn 128 Pekanbaru Kelurahan Rantau Panjang Pekanbaru," J. Pengabdi. Masy. Multidisiplin, vol. 3, no. 1, pp. 29-35, 2019.

[12] N. S. P. Suni, "Kesiapsiagaan Indonesia Menghadapi Potensi Penyebaran Corona," Pus. Penelit. Badan Keahlian DPR RI, vol. XII, no. 3, pp. 14-18, 2020. 